\title{
Observations of Resource Use by the Threatened Diana Fritillary Butterfly (Speyeria diana) in the Southern Appalachian Mountains, USA
}

\author{
Carrie N. Wells ${ }^{1}$ and Eric A. Smith ${ }^{2}$ \\ ${ }^{1}$ Department of Biological Sciences, 132 Long Hall, Clemson University, Clemson, SC 29634, USA \\ ${ }^{2}$ Department of Mathematics and Natural Sciences, Caldwell Community College and Technical Institute, Watauga Campus, \\ Boone, NC 28607, USA \\ Correspondence should be addressed to Carrie N. Wells; carriew@g.clemson.edu
}

Received 21 May 2013; Revised 18 August 2013; Accepted 26 August 2013

Academic Editor: Benjamin Hoffmann

Copyright (c) 2013 C. N. Wells and E. A. Smith. This is an open access article distributed under the Creative Commons Attribution License, which permits unrestricted use, distribution, and reproduction in any medium, provided the original work is properly cited.

\begin{abstract}
We present four summers (2006-2009) of field observations of the Diana fritillary, Speyeria diana (Cramer, 1777), throughout the Southern Appalachian Mountains, USA, in the eastern portion of its distribution. We describe our observations of resource use by $S$. diana in sites located in Georgia, Tennessee, South Carolina, North Carolina, and Virginia. Butterflies imbibed nectar from five genera (>11 species) of flowering plants and also imbibed liquid from dirt roads and horse manure. The majority of butterflies (57\%) were observed feeding on milkweed, Asclepias spp., a high-quality nectar-producing plant which is known to be an important resource for many Lepidoptera. We documented 14 species of Viola spp., the larval host plant used by Speyeria, in our survey sites. All butterflies were marked to observe their movement. Recapture rates ranged from $17 \%$ to $56 \%$, suggesting that dispersal of $S$. diana out of suitable habitat was somewhat limited.
\end{abstract}

\section{Introduction}

The Diana fritillary, Speyeria diana (Cramer, 1777), is an endemic butterfly species in the southeastern USA that has experienced a severe range collapse over the past century [1]. Speyeria diana was once distributed more widely across the southeastern US than it is at the present, ranging from coastal Virginia across the Ohio River Valley to Arkansas and Missouri. This species now persists in two geographically separated population groupings across the Interior Highlands of Arkansas and Oklahoma in the west, and throughout the Southern Appalachian Mountains in the east [1]. Due to its rapid decline over the past century, S. diana is considered to be a species of federal concern in North Carolina by the Fish and Wildlife Service and is included on the North Carolina Animal Watch List published by the North Carolina Natural Heritage Program [2]. Speyeria diana is also included on the Red List of Pollinator Insects of North America, compiled by the Xerces Society for Invertebrate Conservation [3] and is listed by NatureServe as a G3 species (rare across its distribution) [4]. Despite regional listings, there is no federal protection in place for this species under the US Endangered Species Act(16 U.S.C. 1531-1544, 87 Stat. 884).

A number of studies have established the importance of violets, from the genus Viola, to Speyeria larvae [5-7]. While a number of violet species have been used to successfully rear $S$. diana in laboratory settings [8-11], to our knowledge there are no documented reports of Viola usage by $S$. diana from natural habitats. Evidence does suggest that $S$. diana may specialize in its nectar use, preferring high-quality nectar resources when available [12-14]. However, these studies have focused predominately on the western portion of the species' range, largely ignoring the eastern populations. Here, we present our notes on resource use by the Diana fritillary in the Southern Appalachian Mountains, USA, based on four years (20062009) of field observations.

\section{Materials and Methods}

2.1. Study Sites. We surveyed six field sites in the states of Georgia (GA), North Carolina (NC-1, NC-2), South Carolina 


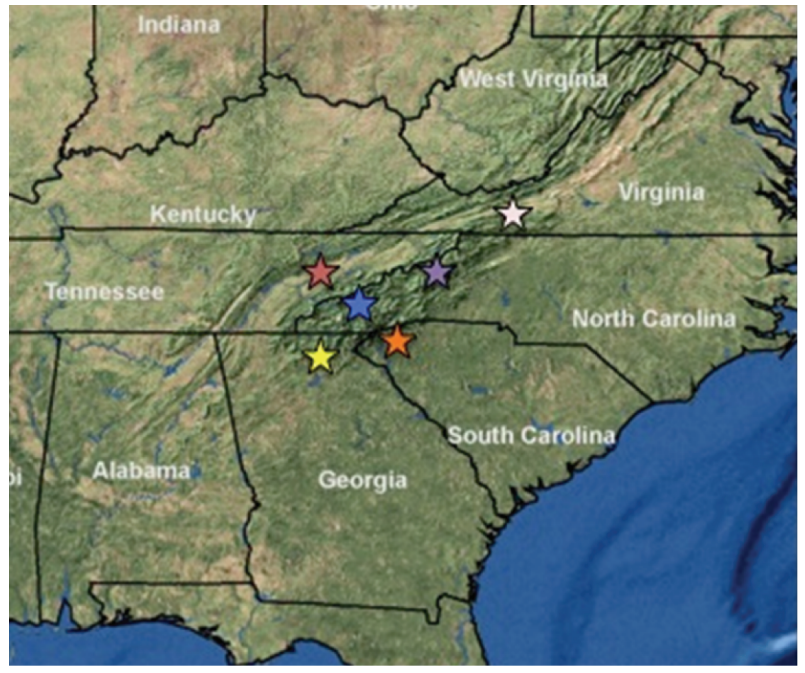

FIgure 1: Southern Appalachian field sites sampled for Speyeria diana summers 2006-2009. From south to north, yellow: GA, orange: SC, blue: NC-1, red: TN, purple: NC-2, and pink: VA.

(SC), Tennessee (TN), and Virginia (VA) from late May to early October during the summers of 2006-2009 (Figure 1). Survey sites were $0.1 \mathrm{ha}$, and they were distributed from the southernmost boundary of the species' eastern range in north Georgia $\left(34.76^{\circ} \mathrm{N},-84.06^{\circ} \mathrm{W}\right)$ to the northernmost boundary of the species' range in Virginia $\left(37.23^{\circ} \mathrm{N},-80.42^{\circ} \mathrm{W}\right)$.

2.2. Surveys. Surveys were conducted between 1000 and $1700 \mathrm{hrs}$ EST on days with temperatures ranging from $19^{\circ}$ to $36^{\circ} \mathrm{C}$. We spent a total of 1,100 hours searching the six field sites for $S$. diana using a combination of slow driving in a motor vehicle ( $5 \mathrm{mi}$ per hr) along dirt roadsides, and hiking into the more remote habitats. For each $S$. diana encountered, we recorded the sex of the butterfly and any nectar source on which the butterfly fed. Horse manure and dirt roads were included because butterflies were observed actively imbibing from these sources. We recorded all violet Viola (Violacea) present in each field site. Plant resources were photographed for later identification when necessary, and all voucher specimens were housed in the Clemson University Arthropod Collection, in Clemson, SC.

We surveyed each site every 14-28 days during the flight period of S. diana (May through October, 2006 to 2009), attempting to capture each $S$. diana encountered in the field with a hand held net. We marked each captured butterflywith a unique number using a sharpie permanent marker, and removed a single leg for genetic studies being conducted by the lead author. Butterflies were handled as gently as possible to minimize wing damage and were released back to the location from which they came. When marked butterflies were recaptured, the date and location of these individuals were noted. Recaptures occurring on the same day of marking the individual were not included, so as not to influence butterfly behavior $[15,16]$.

\section{Results}

3.1. Adult Nectar Plants. We observed S. diana $(N=203)$ feeding on five plant genera, including common milkweed (Asclepias syriaca L.), butterfly milkweed (A. tuberosa L.), thistle (Cirsium spp.), iron weed (Buddleja spp.), goldenrod (Solidago spp.), purple cone flower (Echinacea purpurea L.), butterfly bush (Vernonia spp.), mint (Pycnanthemum), spreading dogbane (Apocynum androsaemifolium L.), blazing star (Liatris spp.), and wild burgemont (Monarda fistulosa L.) (Table 1). Fifty-seven percent of all feeding observations occurred on milkweed, Asclepias spp., followed by thistle, Cirsium spp. (11\%), and Buddleja spp (9\%). Horse manure (6\%) and dirt roads (2\%) were also found to be used by $S$. diana.

3.2. Larval Host Plants. We recorded fourteen Viola spp. across the six field sites (Table 2). The common blue violet, $V$. sororia Willd., was recorded in every field site except South Carolina (Table 2). The second most frequently recorded violet was bird's foot violet, $V$. pedata, which was recorded in four field sites (NC-1, SC, TN, and VA) (Table 2). The Georgia field site appeared to have eight violet species, while the NC-2 site had three species. Viola sagittata and V. rotundifolia were unique to the GA site, while V. appalachiensis was unique to NC-1 site.

3.3. Recaptures. Of the 203 S. diana butterflies we observed feeding, we were able to capture and mark 155 (76\%) of them (Table 3). The highest percent of recapture was from the SC site (56\%), followed by GA (32\%), VA (25\%), TN (21\%), NC$2(21 \%)$, and NC-1 (17\%). The maximum number of times a single individual was recaptured was four (a male from NC2 ), and this individual displayed the longest time between the first and last captures (13 days). Males were more likely to be recaptured than females $\left(\chi^{2}=80.4\right.$, d.f. $\left.=1, P<0.001\right)$. Daily recaptures were too low to reliably estimate population sizes; however, this study was designed primarily to examine butterfly resource use and track movement within sites.

\section{Discussion}

The availability of nectar resources plays an important role in determining the distribution of $S$. diana. This has been previously established in western $S$. diana populations [1719] and is supported by our survey results from the Southern Appalachian Mountains. While our study is purely observational, our results suggest that $S$. diana feeds preferentially on high-quality nectar plants in its eastern distribution, especially milkweed Asclepias spp. High-quality nectar availability is known to be an important resource in other endangered fritillaries as well $[20,21]$. It has been suggested that phytochemicals present in the nectar of certain flowers, such as Asclepias spp. and Echinacea spp., may help protect long-lived $S$. diana females as well as overwintering $S$. diana larvae, from microbes, fungus, and disease [13]. It has recently been shown that amino acids from nectar can enhance female butterfly reproduction $[19,20]$, as well as male butterfly reproduction $[21,22]$. Amino acids and electrolytes present in horse dung, 
TABLE 1: Feeding observations ( $N=203)$ of male/female Speyeria diana (2006-2009) in six field sites located across the Southern Appalachian Mountains, and the percentage of total use of each resource. Horse manure and dirt roads were included, as butterflies were observed actively imbibing from these sources.

\begin{tabular}{|c|c|c|c|c|c|c|c|}
\hline Nectar source & GA & NC-1 & NC-2 & SC & $\mathrm{TN}$ & VA & Percentage of total \\
\hline Asclepias syriaca L. & $5 / 0$ & $6 / 0$ & & & $42 / 1$ & $30 / 2$ & $43 \%$ \\
\hline Asclepias tuberosa $\mathrm{L}$. & $9 / 1$ & & & $5 / 1$ & $7 / 0$ & $5 / 0$ & $14 \%$ \\
\hline Cirsium spp & $0 / 5$ & $0 / 9$ & & $3 / 2$ & $1 / 3$ & & $11 \%$ \\
\hline Buddleja L. spp & & & $10 / 4$ & $4 / 0$ & & & $9 \%$ \\
\hline Solidago spp & & $5 / 1$ & & $3 / 1$ & & $2 / 0$ & $6 \%$ \\
\hline Echinacea purpurea L. & $2 / 0$ & $4 / 1$ & & $1 / 0$ & & & $4 \%$ \\
\hline Vernonia spp & & $3 / 0$ & $2 / 1$ & & & & $3 \%$ \\
\hline Pycnanthemum Michx. & & & & & & $2 / 0$ & $1 \%$ \\
\hline Apocynum androsaemifolium $\mathrm{L}$. & & & & $0 / 1$ & $1 / 0$ & & $1 \%$ \\
\hline Liatris spp & $1 / 0$ & & & & & $0 / 1$ & $1 \%$ \\
\hline Monarda fistulosa L. & & $1 / 0$ & & & & & $0.5 \%$ \\
\hline Horse manure & $4 / 0$ & $4 / 0$ & & & $5 / 0$ & & $6 \%$ \\
\hline Dirt road & & $1 / 0$ & & & $1 / 0$ & & $2 \%$ \\
\hline
\end{tabular}

TABLE 2: Violet (Viola spp.) larval host plants observed at each of the Southern Appalachian field sites (2006-2009).

\begin{tabular}{lcccccc}
\hline & GA & NC-1 & NC-2 & SC & TN & VA \\
\hline Viola appalachiensis Henry & & $\mathrm{X}$ & & & & \\
V. bicolor Pursh. & & & & $\mathrm{X}$ & $\mathrm{X}$ & \\
Viola blanda Willd. & & $\mathrm{X}$ & & $\mathrm{X}$ & $\mathrm{X}$ & \\
V. canadensis L. & $\mathrm{X}$ & & & & $\mathrm{X}$ & $\mathrm{X}$ \\
V. cucullata Aiton & $\mathrm{X}$ & $\mathrm{X}$ & & $\mathrm{X}$ & & \\
V. hirsutula Brainerd & & & & $\mathrm{X}$ & & $\mathrm{X}$ \\
V. lanceolata L. & & $\mathrm{X}$ & & & & \\
V. papilionacea Pursh. & $\mathrm{X}$ & & $\mathrm{X}$ & & & $\mathrm{X}$ \\
V. pedata L. & & $\mathrm{X}$ & & $\mathrm{X}$ & $\mathrm{X}$ & $\mathrm{X}$ \\
V. pubescens Aiton & $\mathrm{X}$ & & $\mathrm{X}$ & & $\mathrm{X}$ & \\
V. rotundifolia Michx. & $\mathrm{X}$ & & & & & \\
V. sagittata Aiton & $\mathrm{X}$ & & & & & $\mathrm{X}$ \\
V. sororia Willd. & $\mathrm{X}$ & $\mathrm{X}$ & $\mathrm{X}$ & & $\mathrm{X}$ & $\mathrm{X}$ \\
V. tricolor L. & $\mathrm{X}$ & & & & & $\mathrm{X}$ \\
\hline
\end{tabular}

and some soils, are also known to provide butterflies with a rich source of nutrients [23].

The presence of particular Viola species did not appear to influence the activity of butterflies in our field sites. This result is consistent with laboratory rearing trials, which have not found any evidence of Viola preference in reproducing S. diana females, or developing larvae [11]. All of the violet species observed in this study are widely distributed in southeastern US forests [24].

Mark-release-recapture (MRR) techniques are used widely to estimate the population parameters of vagile species [25]. Our recapture rate of S. diana in the field was larger than expected; however, we want to emphasize that our markrelease-recapture methods were not intended to estimate $S$. diana population size in the field. We report our markrelease-recapture data for several reasons. First, we believe that our high recapture rate supports the hypothesis that
TABle 3: Total number of feeding observations of Speyeria diana at each field site and the total number of butterflies captured and recaptured (2006-2009).

\begin{tabular}{lcccc}
\hline $\begin{array}{l}\text { Field } \\
\text { site }\end{array}$ & $\begin{array}{c}\text { Number of } \\
\text { feeding } \\
\text { observations } \\
(N=203)\end{array}$ & $\begin{array}{c}\text { Number of } \\
\text { marked } \\
\text { butterflies } \\
(N=155)\end{array}$ & $\begin{array}{c}\text { Number of } \\
\text { recaptures } \\
(N=41)\end{array}$ & $\begin{array}{c}\text { Percent } \\
\text { recapture }\end{array}$ \\
\hline GA & 27 & 19 & 6 & $32 \%$ \\
NC-1 & 35 & 18 & 3 & $17 \%$ \\
NC-2 & 17 & 14 & 3 & $21 \%$ \\
SC & 21 & 16 & 9 & $56 \%$ \\
TN & 61 & 52 & 11 & $21 \%$ \\
VA & 42 & 36 & 9 & $25 \%$ \\
\hline
\end{tabular}

S. diana is a highly localized species that does not disperse widely from a local habitat once it becomes established. We recaptured a large number of both males and females in all field sites, sometimes just meters from the butterfly's original location. Some recaptures occurred weeks after marking, further supporting the limited dispersal of $S$. diana over time as an adult. Second, the high recapture rate of $S$. diana also indicates that our nonlethal method of removing a single leg for genetic sampling did not negatively affect individual butterflies. The fact that a large number of butterflies were resampled several months after their initial capture suggests that these butterflies stayed in the local vicinity of the sampling site for the duration of their adult life without suffering demise resulting from the removal of a single leg.

Despite the importance of nectar resources in butterfly habitat, nectar plant use remains unstudied for many species on a small enough spatial scale [26]. Our observations of $S$. diana in the Southern Appalachian Mountains support the idea that this species is a specialist in its nectar use, preferring some sources of high-quality nectar over other sources. Our observations provide a preliminary list of nectar resources that can be targeted for preservation in S. diana, and other 
fritillary habitat. Our observations also confirm the importance of Asclepias spp. to butterfly communities, a nectar plant that is required by the long-distance migrant, the monarch butterfly, Danaus plexippus [27]. Increased planting of high-quality nectar plants, like milkweed and Echinacea, in butterfly gardens and urban areas may benefit a large number of butterfly species, especially those that are long-lived like $D$. plexippus and S. diana.

\section{Acknowledgments}

This project was funded by the Sarah Bradley Tyson Memorial Fellowship awarded to the lead author by the Woman's National Farm \& Garden Association, Inc. We would like to thank Irving Finkelstein, Harry King, Harry Legrand, Thomas Payne, William Garthe, Connie Wells, Philip Wells, and the students from Clemson University's Creative Inquiry Program for their help with this project.

\section{References}

[1] C. N. Wells and D. W. Tonkyn, "Range collapse in the Diana fritillary," Insect Conservation and Diversity. In press.

[2] H. E. Legrand, J. T. Finnegan, S. P. Hall, A. J. Leslie, and J. A. Ratcliffe, Natural Heritage Program List of the Rare Animal Species of North Carolina, North Carolina Natural Heritage Program, Office of Conservation and Community Affairs. North Carolina Department of Environment and Natural Resources, Raleigh, NC, USA, 2012.

[3] D. M. Vaughan and M. D. Shepherd, "Species profile: Speyeria diana," in Red List of Pollinator Insects of North America. CDROM Version 1, M. D. Shepherd, D. M. Vaughan, and S. H. Black, Eds., The Xerces Society for Invertebrate Conservation, Portland, Ore, USA, 2005.

[4] Natureserve, "NatureServe Explorer: An online encyclopedia of life [web application]. Version 7. 0," NatureServe, Arlington, Va, USA, 2013, http://www.natureserve.org/explorer.

[5] A. B. Swengel, "Habitat associations of sympatric violet-feeding fritillaries (Euptoieta, Speyeria, Boloria) (Lepidoptera: Nymphalidae) in tallgrass prairie," Great Lakes Entomologist, vol. 30, no. 1-2, pp. 1-18, 1997.

[6] L. Kelly and D. M. Debinski, "Relationship of host plant density to size and abundance of the regal fritillary Speyeria idalia Drury (nymphalidae)," Journal of the Lepidopterists' Society, vol. 52, no. 3, pp. 262-276, 1998.

[7] B. J. Kopper, R. E. Charlton, and D. C. Margolies, "Oviposition site selection by the regal fritillary, Speyeria idalia, as affected by proximity of violet host plants," Journal of Insect Behavior, vol. 13, no. 5, pp. 651-665, 2000.

[8] W. H. Edwards, "Notes on the larvae of Argynnis cybele, aphrodite, and diana," The Canadian Entomologist, vol. 6, pp. 121-125, 1874.

[9] W. H. Evans, "The saga of an orphan Speyeria diana larva," Journal of the Lepidopterists' Society, vol. 13, pp. 93-95, 1959.

[10] S. O. Matoon, R. D. Davis, and O. D. Spencer, "Rearing techniques for for species of Speyeria (Nymphalidae)," Journal of the Lepidopterists' Society, vol. 25, pp. 247-255, 1971.

[11] C. N. Wells, L. Edwards, R. Hawkins, L. Smith, and D. Tonkyn, "A rearing method for Argynnis (Speyeria) diana (Lepidoptera: Nymphalidae) that avoids larval diapause," Psyche, vol. 2011, Article ID 940280, pp. 1-6, 2011.
[12] M. D. Moran and C. D. Baldridge, "Distribution of the Diana Fritillary, Speyeria diana (Nymphalidae) in Arkansas, with notes on nectar plant and habitat preference," Journal of the Lepidopterists' Society, vol. 56, no. 3, pp. 162-165, 2002.

[13] G. N. Ross, "What's for dinner? A new look at the role of phytochemicals in butterfly diets," News of the Lepidopterists' Society, vol. 45, pp. 83-89, 2003.

[14] D. C. Rudolph, C. A. Ely, R. R. Schaefer, J. H. Williamson, and R. E. Thill, "The Diana fritillary (Speyeria diana) and great spangled fritillary (S. cybele): dependence on fire in the Ouachita Mountains of Arkansas," Journal of the Lepidopterists' Society, vol. 60, no. 4, pp. 218-226, 2006.

[15] L. F. Gall, "The effects of capturing and marking on subsequent activity in Boloria acrocnema (Lepidoptera: Nymphalidae), with a comparison of different numerical models that estimate population size," Biological Conservation, vol. 28, no. 2, pp. 139154, 1984.

[16] A. C. Morton, "The effects of marking and handling on recapture frequencies of butterflies," in The Biology of Butterflies, P. R. Ackery and R. I. Vane-Wright, Eds., pp. 55-58, Princeton University Press, Princeton, NJ, USA, 1984

[17] H. B. Britten and L. Riley, "Nectar source diversity as an indicator of habitat suitability for the endangered Uncompahgre fritillary, Boloria acrocnema (Nymphalidae)," Journal of the Lepidopterists' Society, vol. 48, no. 3, pp. 173-179, 1994.

[18] R. E. Latham, D. Zercher, P. McElhenny, P. Mooreside, and B. Ferster, "The role of disturbance in habitat restoration and management for the eastern regal fritillary (Speyeria idalia idalia) at a military installation in Pennsylvania," Ecological Restoration, vol. 25, no. 2, pp. 103-111, 2007.

[19] J. Mevi-Schütz and A. Erhardt, "Amino acids in nectar enhance butterfly fecundity: a long-awaited link," American Naturalist, vol. 165, no. 4, pp. 411-419, 2005.

[20] F. Cahenzli and A. Erhardt, "Enhancing offspring quality or quantity? Different ways for using nectar amino acids in female butterflies," in Oecologia, vol. 169, pp. 1005-10014, 2012.

[21] F. Cahenzli and A. Erhardt, "Nectar sugars enhance fitness in male Coenonympha pamphilus butterflies by increasing longevity or realized reproduction," Oikos, vol. 121, pp. 1417-1423, 2012.

[22] F. Cahenzli and A. Erhardt, "Nectar amino acids enhance reproduction in male butterflies," Oecologia, vol. 171, pp. 197-205, 2013.

[23] S. R. Smedley and T. Eisner, "Sodium uptake by puddling in a moth," Science, vol. 270, no. 5243, pp. 1816-1818, 1995.

[24] F. S. Gilliam, N. L. Turrill, and M. B. Adams, "Herbaceouslayer and overstory species in clear-cut and mature central Appalachian hardwood forests," Ecological Applications, vol. 5, no. 4, pp. 947-955, 1995.

[25] T. R. E. Southwood and P. A. Henderson, Ecological Methods, Blackwell, Oxford, UK, 3rd edition, 2000.

[26] M. Ezzeddine and S. F. Matter, "Nectar flower use and electivity by butterflies in sub-alpine meadows," Journal of the Lepidopterists' Society, vol. 62, no. 3, pp. 138-142, 2008.

[27] C. N. Wells, "An ecological field lab for tracking monarch butterflies \& their parasites," American Biology Teacher, vol. 72, no. 6 , pp. 339-344, 2010. 

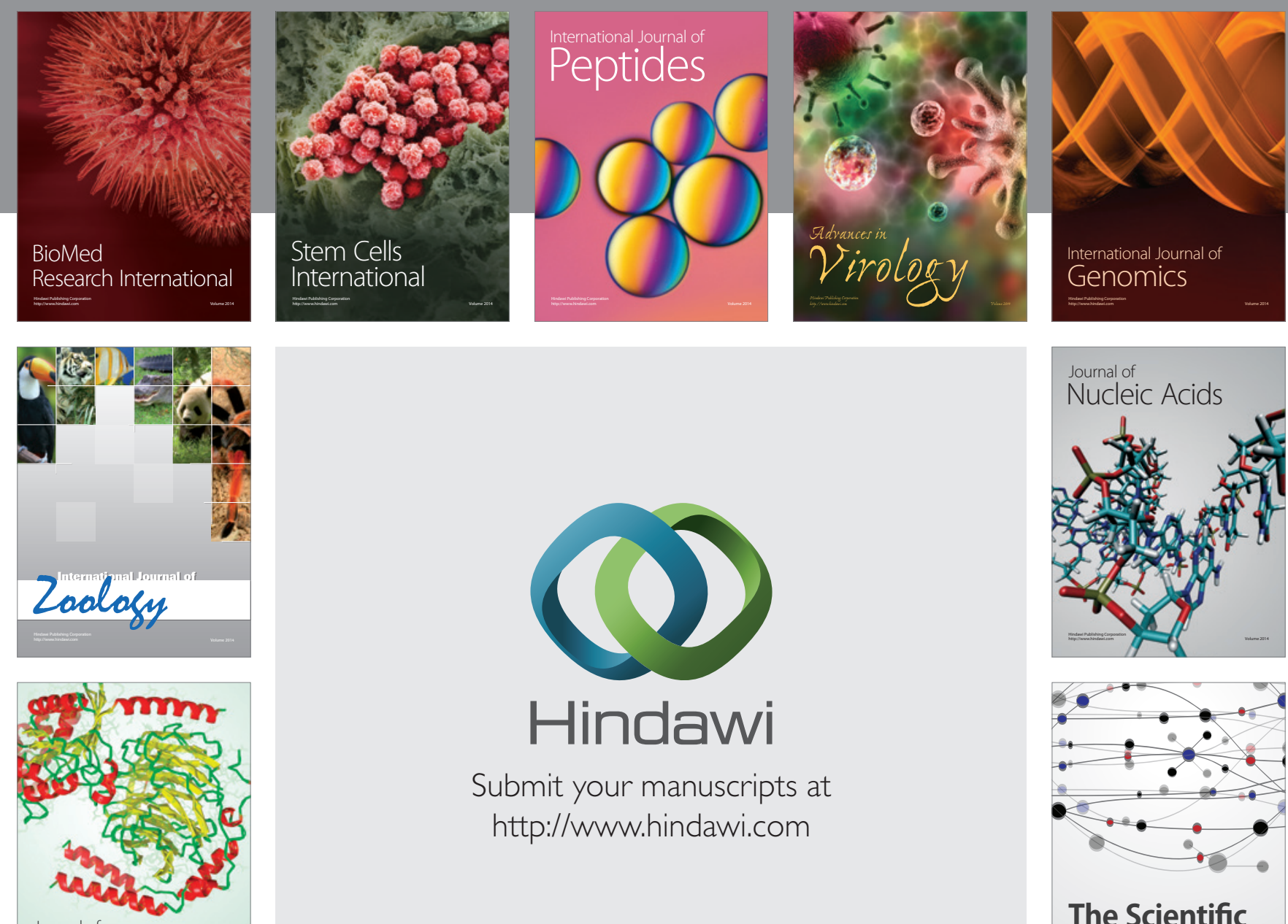

Submit your manuscripts at

http://www.hindawi.com

Journal of
Signal Transduction
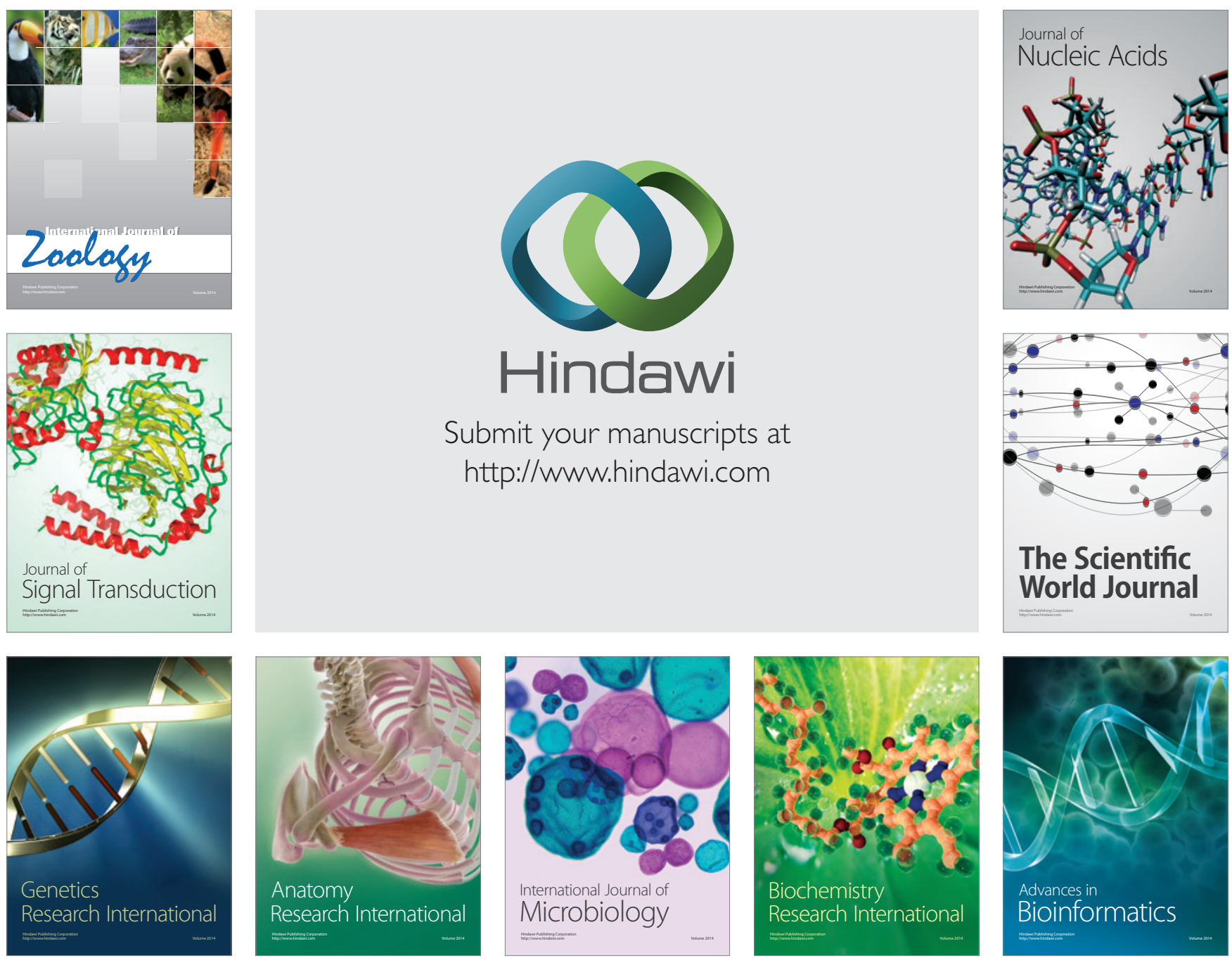

The Scientific World Journal
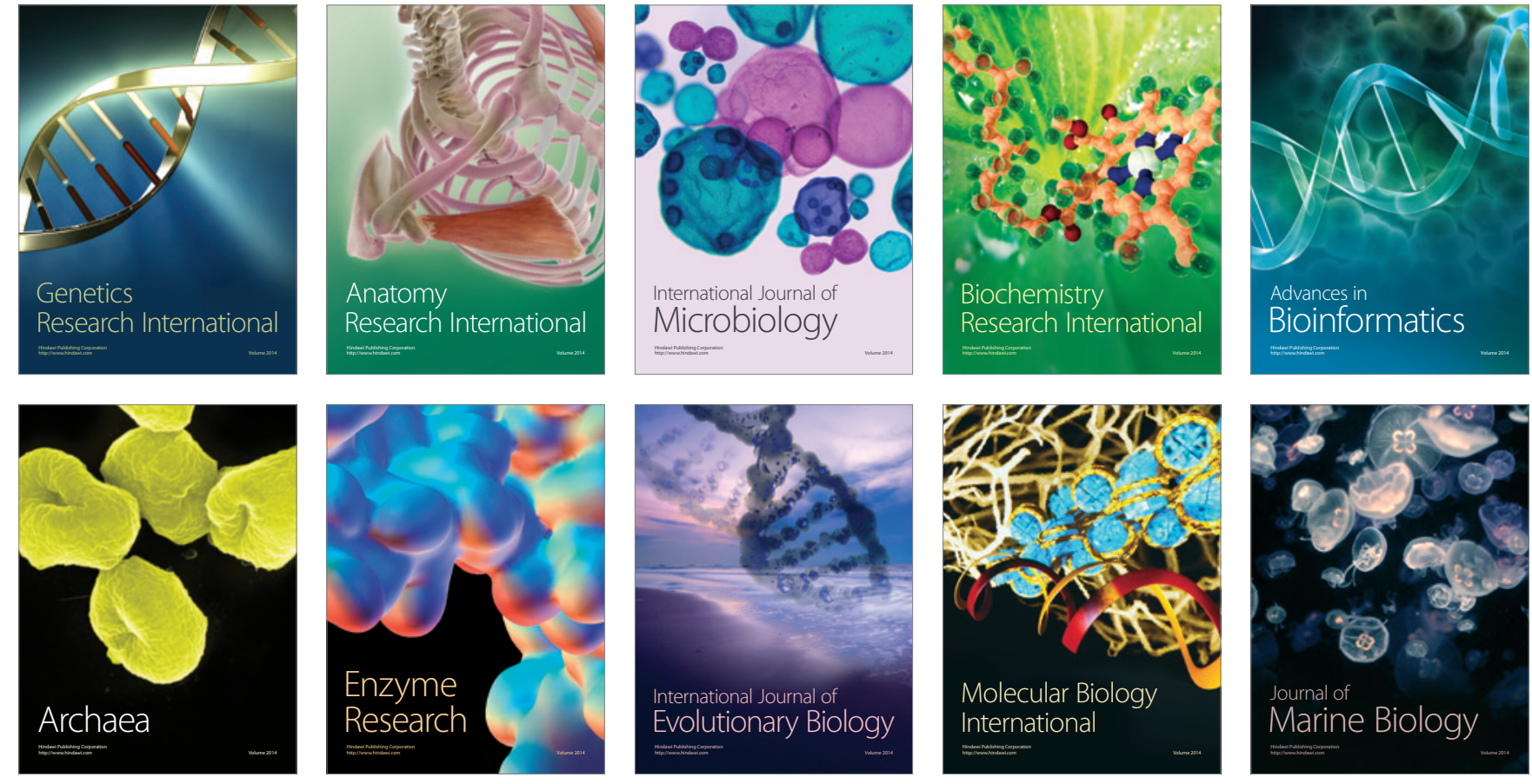